\title{
HARPACTICOIDA COPEPOD ASSOCIATED TO MACROALGAE Himantothallus grandifolius (OCHROPHYTA, DESMARESTIACEAE) FROM ADMIRALTY BAY (KING GEORGE ISLAND, SOUTH SHETLANDS ISLANDS, MARITIME ANTARCTICA)
} http://dx.doi.org/10.4322/apa.2014.114

Rafael Tostes Salazar*, Geyze Magalhães de Faria, Tais Maria de Souza Campos, Adriana Galindo Dalto** Laboratório de Macroalgas Marinhas, Instituto de Biologia, Universidade Federal do Rio de Janeiro - UFRJ, Avenida Brigadeiro Trompowski s/nº, CEP 21044-020, Rio de Janeiro, RJ, Brazil

e-mail:*rafae/14th@hotmail.com; **agdalto@gmail.com

\begin{abstract}
This research work is a pioneer study related to the Harpacticoida Copepod species of the phytal environment of Antarctica, contributing to the knowledge of the biodiversity of copepods, associated to the macroalgae of Admiralty Bay, especially those of the Harpacticoida Order. Samples of the four genus types of Harpacticoida Copepod were found in a macroalgae (Himantothallus grandifolius) especially in its appressoria, collected in the melt water area of Admiralty Bay, King George Island, Archipelago, South Shetlands, Antarctica: Stygonitocrella (Ameiridae Family), Porcellidium (Porcellidiidae Family), Alteutha potter (Peltidiidae Family), Tisbisoma (Paramesochridae Family). The copepods found in this study possess adaptation qualities that may facilitate the exploration of macroalgae, such as: epibenthic body format, which allows greater swimming capacity or a dorso-ventrally flattened body, with prehensile first pair of legs or with a large maxilliped subchelate, the latter being adaptations to be able to fix itself to thalloid surfaces, in locations with strong water currents. The genus Porcellidium and the Paramesochridae Family are frequently found associated to macroalgae. Alteutha potter is described in literature as planktonic. However, we suggest that the specie can be benthonic and is capable of migrating to zooplankton. Stygonitocrellaé is described as a species of continental and subterranean waters. The fact that algae have been found at just $15 \mathrm{~m}$ depth with strong water melt current can help explain its presence. The identifications continue underway and include analysis of phytal samples of other macroalgae collected in the Admiralty Bay from 2010 to 2011.
\end{abstract}

Keywords: Harpacticoida, Antarctica, Macroalgae, Phytal

\section{Introduction}

Benthic harpacticoid copepods occur with frequency associated to marine macroalgae, being part of the phytal meiofauna (Moore,1973). The marine macroalgae (kelps) have an important function in these regions. They influence the patterns of distribution and diversity of many marine organisms, by indirectly modifying the physical factors such as light intensity and flow of local water (Reed \& Foster, 1984; Bulleri et al., 2002). The number of ecological niches and forms or usage of environmental resources can be potentially greater in these habitats (Tews et al., 2004). At present, the marine macroalgae banks are considered to be the hotspots of Antarctic biodiversity (Gray, 2001).

In Admiralty Bay the macroalgae Himantothallus grandifolius forms large aggregates in the subtidal bottom between 10 and 100 metres deep. This kelp with coral coloured thallus in the form of a tongue (himanto) and with wavy edges, can reach more than 10 metres in length and 1 metre wide (Dieckmann et al., 1985; Zieliński, 1990), having circumpolar distribution (Skottsberg, 1964) and it is common in the subtidal rocky region of Maritime Antarctica 
(Moe \& Silva, 1977, 1981). The thallus and holdfast of this alga are considered to be complex habitats (Steneck et al., 2002) and can shelter a great variety of associated organisms.

In this context, the present study intends to contribute to the knowledge of the biodiversity of copepods associated to macroalgae in Admiralty Bay, especially those of the Harpacticoida Order.

\section{Materials and Methods}

The macroalgae Himantothallus grandifolius was collected in February 2011 in Mackellar Inlet (Admiralty Bay, King George Island, Maritime Antarctica) at a depth of 15 metres (Figure 1). The thallus of the H. grandifolius specimen measured $8 \mathrm{~m}$ in length and was $60 \mathrm{~cm}$ wide, with $45 \mathrm{~cm}$ diameter in its appressoria (Figure 2). In the laboratory, the associated fauna was separated by means of sieves of 500 and $32 \mu \mathrm{m}$ fixed in formaldehyde neutralized at $4 \%$. The copepods were firstly sorted by means of a stereomicroscope and separated by Order. Afterwards the taxonomic identifications by Family and genera of the Harpacticoida were undertaken through observation under an optical microscope, based on specific literature for this Order (Lang, 1948, 1965; Huys et al., 1996; Boxshall \& Halsey, 2004). After identification, the specimens were photographed and schematized through camera lucida.

\section{Results}

The absolute density of Harpacticoida copepods associated to H. Grandifolius reached 239 individuals, originating principally from the holdfast of these algae. Amongst these were identified up to the moment one specie and three more genera originating from four

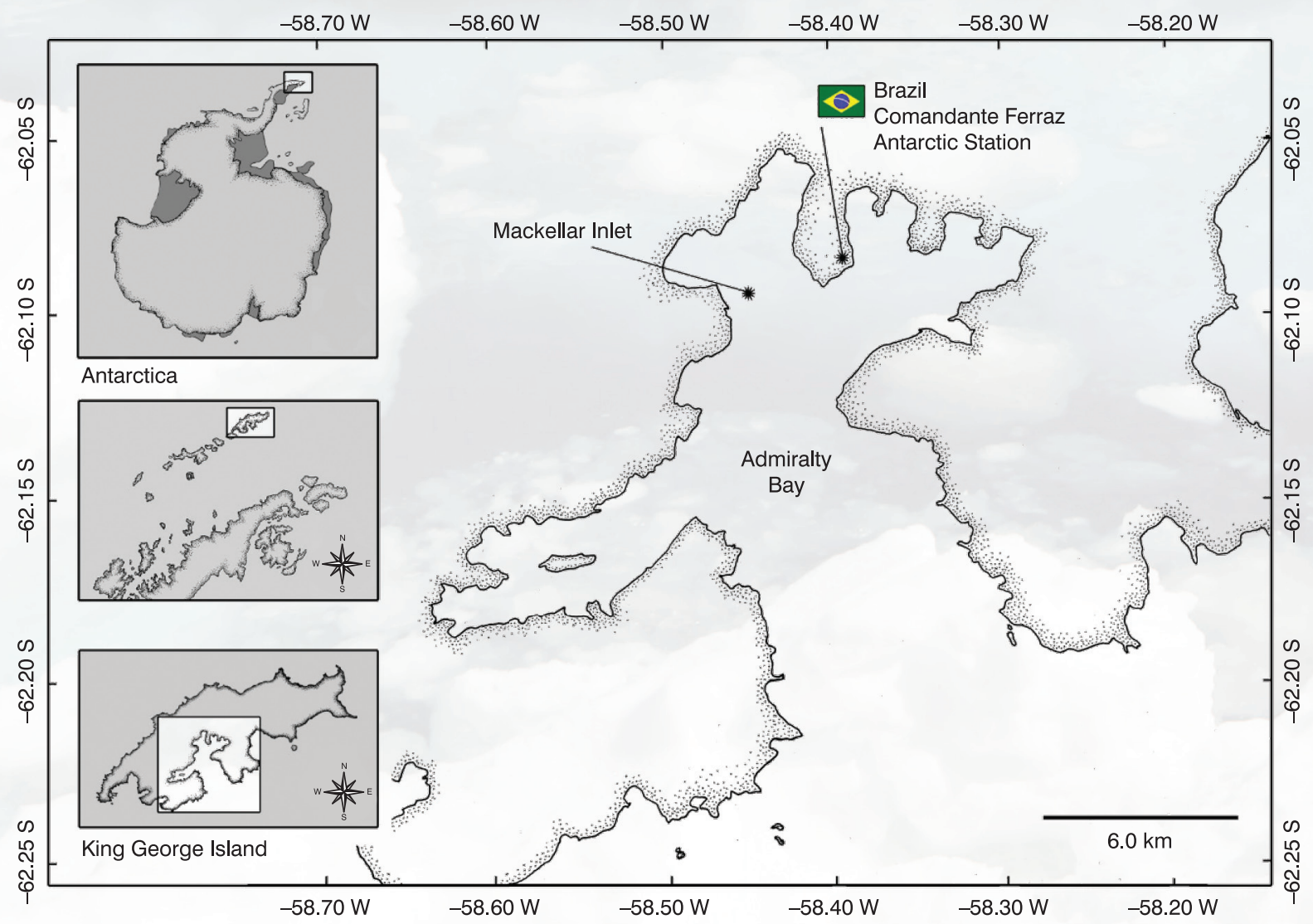

Figure 1. Study área and sampling station in Mackellar Inlet, Admiralty Bay, King George Island (Illustration: Rafael Bendayan de Moura). 
families: Alteutha potter (Peltidiidae Family), Stygonitocrella (Ameiridae Family), Porcellidium (Porcellidiidae Family), Tisbisoma (Paramesochridae Family) (Figure 3).

The individuals identified as being of the Tisbisoma genus had the body of a ciclopiform, as if they were, according to Boxshall \& Halsey (2004) of the primitive Paramesochridae. The copepods of the Porcellidiidae Family, like those of the Peltidium genus, identified in present study, have a strongly flattened body and ventral sucking disc, which helps to fix its classification among the macroalgae (Boxshall \& Halsey, 2004). A. potter, as well as the other members of the gender Alteutha have a dorso-ventrally flattened body and are strongly chitinised with developed appendices and strong subchelate maxiliped (Veit-Köhler \& Fuentes, 2007). Stygonitocrella has a cylindrical body, reduced P2$\mathrm{P} 4$ appendices and endopodite of $\mathrm{P} 4$ with just one vestigial segment.

\section{Discussion and Conclusion}

The copepods of this study have adaptation qualities for life in the phytal ecosystem. The individuals identified as belonging to the genus Tisbisoma Bozic, 1964 possess the body of the ciclopiform. Because of this factor, it probably has greater capacity to swim and this could be an

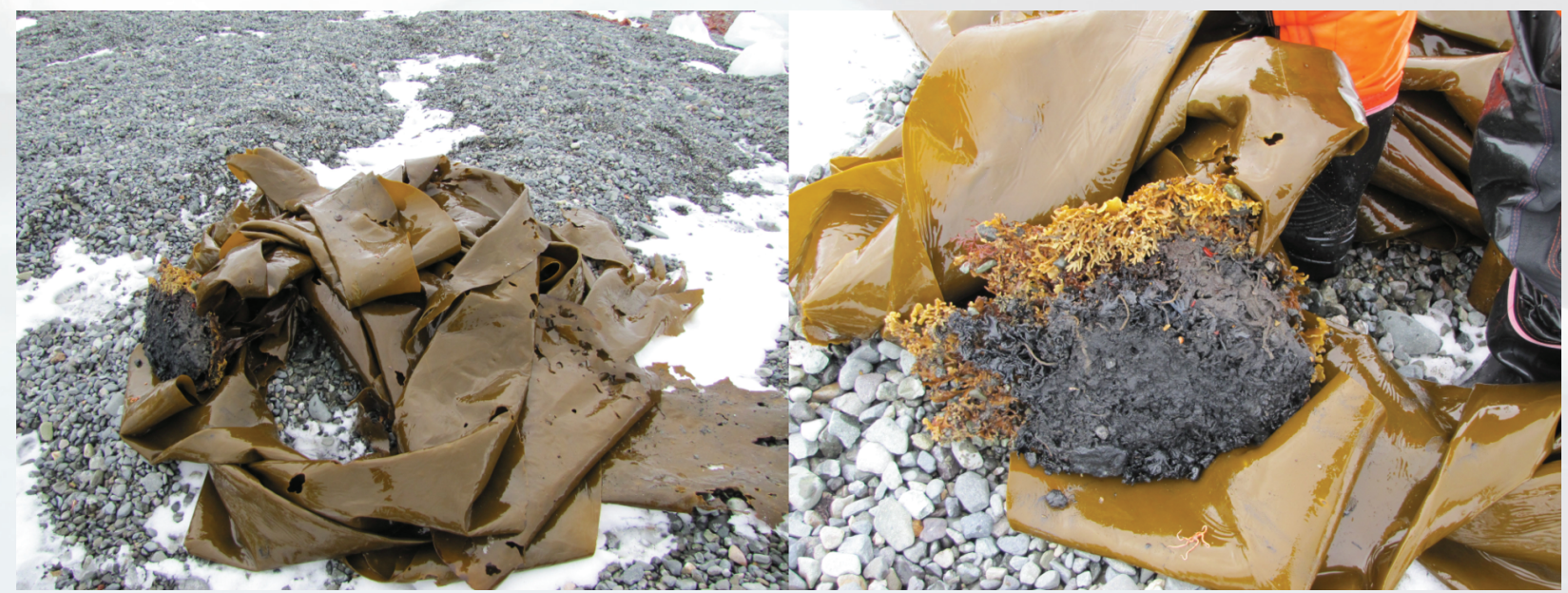

Figure 2. Himantothallus grandifolius (length: $8 \mathrm{~m}$; width: $60 \mathrm{~cm}$; diameter of the holdfast: $45 \mathrm{~cm}$ )
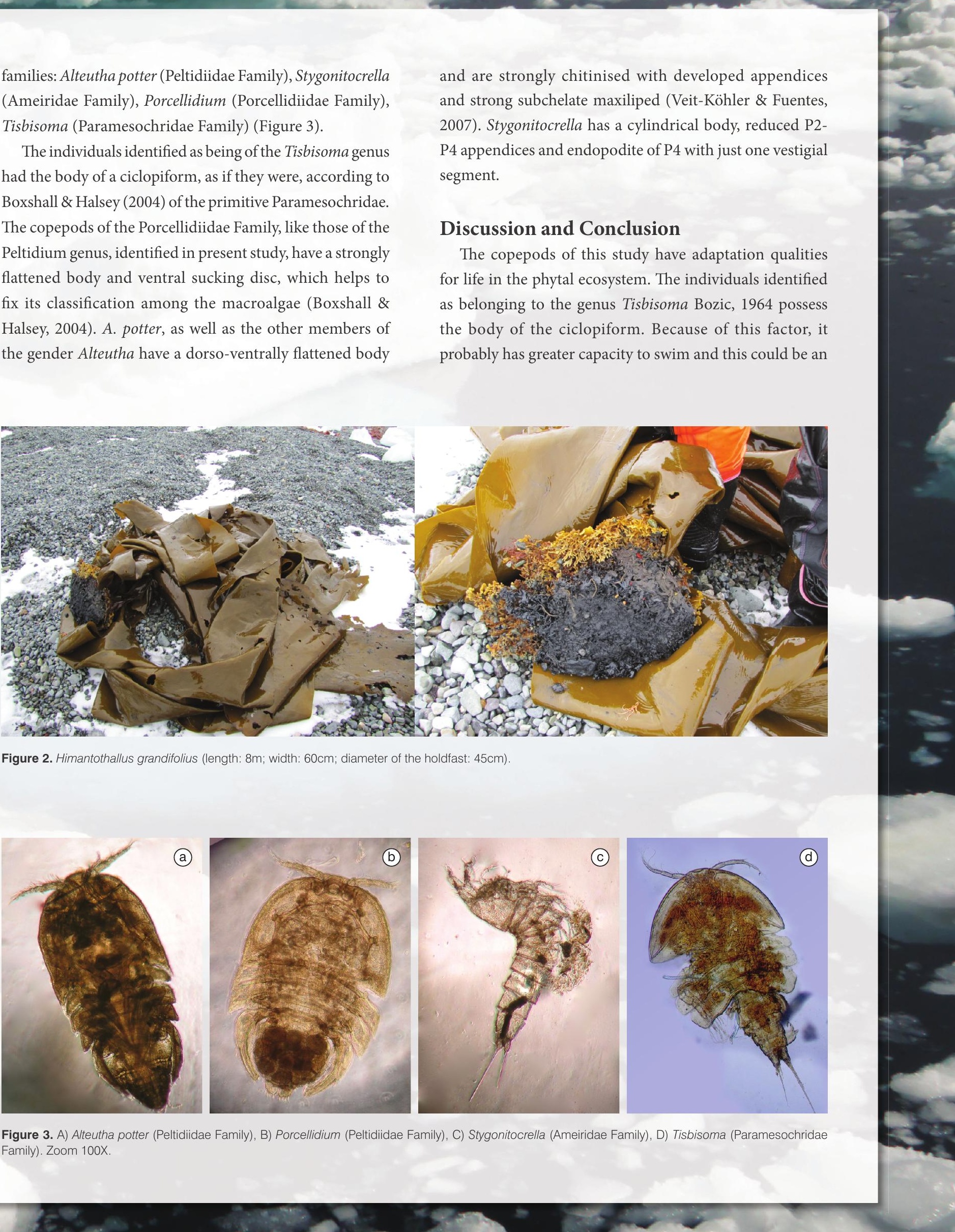

Figure 3. A) Alteutha potter (Peltidiidae Family), B) Porcellidium (Peltidiidae Family), C) Stygonitocrella (Ameiridae Family), D) Tisbisoma (Paramesochridae Family). Zoom 100X 


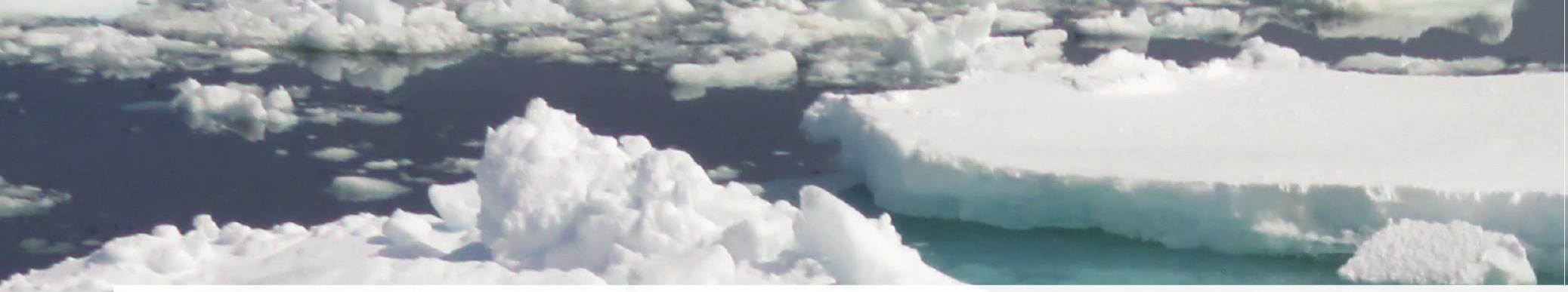

advantageous characteristic to colonize macroalgae, when compared to interstitial forms of Harpacticoida (Hicks, 1986; Boxshall \& Halsey, 2004). The copepods of the Porcellidiidae and Peltidiidatrae families, including the respective genders identified in this study (Alteutha e Porcellidium), have strongly flattened body and are commonly found associated to macroalgae, being considered algal-dwellers, or live in sediment, where they have epibenthic habitation. Porcellidiideos have furthermore a ventral sucking disc, which helps to fix them in the macroalgae (Boxshall \& Halsey, 2004). A. potter, has like other species of the same genus, may have a greater capacity to swim in relation to the other Harpacticoida copepods, being probably a potential predator (Veit-Köhler \& Fuentes, 2007). All these characteristics combined are important to overcome the strong currents that occur on the thalloid surfaces of some algae.

The Peltidiidae Family is regularly reported in samples of plankton (Hicks, 1986). The genus Alteutha is commonly found in the Antarctic and Sub-Antarctic water, where 10 of its 16 valid species can occur (Veit-Köhler \& Fuentes, 2007). Recently, Veit-Köhler \& Fuentes (2007) identified a new species of this gender (A. potter) in samples of zooplankton of Potter Cove, located to the Southwest of the King George Island (Archipelago, South Shetlands). These authors found $A$. potter in greater densities, in the samples close to the sea ice, formulating furthermore the hypothesis that these copepods are benthonic and migrate to zooplankton colonizing the habitats proportioned by the ice. According to Veit-Köhler \& Fuentes (2007), it is not possible to sample the copepods of the Potter Cove sediment and perhaps these could be found associated to the macroalgae of the region, such as $H$. grandifolius, which is also found in Potter Cove. This study found A. potter associated to H. grandifolius in the Mackellar Inlet, in Admiralty bay which is close to Potter Cove, some data which contributes to the confirmation of the hypothesis. In the future, new studies could be undertaken comparing the associated fauna to the macroalgae of Admiralty bay and Potter Cove.

Stygonitocrella is described as exclusive of continental waters, groundwater and coastal waters with the intake of fresh water (Boxshall \& Halsey, 2004; Suárez-Morales \& Llife, 2005). In spite of having been found in the marine environment, Himantothallus grandifolius was collected in shallow waters, in Admiralty bay, where there is strong intake of fresh water, including melt water. Even so, it is necessary to confirm the finding, since the Ameiridae family still needs to be revised (Boxshall \& Halsey, 2004).

The identifications of these and other phytal samples, collected in Admiralty bay between 2010 and 2011, continue underway.

\section{Acknowledgements}

This works integrates the National Institute of Science and Technology Antarctic Environmental Research (INCTAPA) that receives scientific and financial support from the National Council for Research and Development (CNPQ process: 574018/2008-5) and Carlos Chagas Research Support Foundation of the State of Rio de Janeiro (CAPES/ FAPERJ process: E-26/102.016/2009) for the scientific and financial support including the grants awarded.

\section{References}

Boxshall, G.A. \& Halsey S.H. (2004). An introduction to copepod diversity. London: The Ray Society, 966 p.

Bulleri, F.; Benedetti-Cecchi, L.; Acunto, S.; Cinelli, F. \& Hawkins, S.J. (2002). The influence of canopy algae on vertical. Journal of experimental Marine Biology and Ecology, 267: 89-106.

Dieckmann, G.; Reichardt, W. \& Zieliński, K. (1985). Growth and production of the seaweed, Himantothallus grandifolius, at King George Island. In: Siegfried, W.R.; Condy, P.R. \& Laws, R.M. Antarctic Nutrient Cycles and Food Webs. Berlin, Springer, 104-108.

Gray, J.S. (2001). Marine diversity: the paradigms in patterns of species richness examined. Scientia Marina, 65: 41-56. 
Hicks, G.R.F. (1986). Distribution and behaviour of meiofaunal copepods inside and outside seagrass beds. Marine Ecology Progress Series, 31: 159-170.

Huys, R.; Gee, J.M.; Moore, C.G. \& Hamond, R. (1996). Marine and brackish water harpacticoid copepodods. Part 1. In: Barnes, R.S.K. and Crothers, J.H. (eds.), Synopses of the British Fauna (New Series), 51: 1-352.

Lang, K.; (1948). Monographie der Harpacticiden I und II. Reprint Koeltz Science Publ.; Königstein. Germany.

Lang, K.; (1965). Copepoda Harpacticoidea from the Californian Pacific coast.—Kungliga Svenska Vetenskapsakademiens Handlingar (Series 4), 10(2):1-560.

Moore, C.G. (1973). The kelp fauna of Northest Britain. Multivariate Classification: Turbidity as anecological factor. Journal of Experimental Marine Biology and Ecology, 13: 127-163.

Moe, R. L. \& Silva, P. C. (1977). Sporangia in the brown algal genus Desmarestia with special reference to Antarctic D. ligulata. Bulletin of the Japanese Society for Phycology, 25(Suppl.): 157-167.

Reed, D.C. \& Foster, M.S. (1984). The effects of canopy shadingon algal recruitment and growth in a giant kelp forest. Ecology, 65: 937-948.

Skottsberg, C. J. F. (1964). Antarctic Phycology. In: Carrick, R.; Holgate, M. y Prevost, J. (eds) Biologie Antarctique. 1st S.C.A.R. Symposium. Hermann, Paris: 147-154.

Steneck, R.S.; Graham, M.H.; Bourque, B.J.; Corbett, D.; Erlandson, J.M.; Estes, J.A. \& Tegner, M.J. (2002). Kelp forest ecosystems: Biodiversity, stability, resilience and future. Environmental Conservation, 29: 436-459.

Suárez-Morales, E. \& Llife, T.M. (2005). A new Stygonitocrella Petkovski (copepoda: Harpacticoida) from a cave in Northern Mexico with comments on the taxonomy of the genus. Hydrobiologia, 544:215-228.

Tews, J.; Brose, U.; Grimm, V.; Tielborger, K.; Wichmann, M.C.; Schwager, M. \& Jeltsch, F. (2004). Animal species diversity driven by habitat heterogeneitiy/diversity: the importance of keystone structures. Journal of Biogeography, 31 : 79-92.

Veit-Köhler, G. \& Fuentes, V. (2007). A new pelagic Alteutha (Copepoda: Harpacticoida) from Potter Cove, King George Island, Antarctica-description, ecology and information on its year round distribution. Hydrobiologia, 583:141-163.

Zieliński, K. (1990). Bottom macroalgae of Admiralty Bay (King George Island, South Shetland Islands, Antarctica). Polish Polar Research, 11 (12): 95-131. 